\title{
Trends, Issues, and Community Participation in to Prevent Sexual Violence in Children at Sleman Regency, Yogyakarta
}

\author{
${\text { Yustiana } \text { Olfah }^{1}, \text { A. A. Subiyanto }}^{1}$, Sapja Anantayu ${ }^{1} \&$ Mahendra Wijaya $^{1}$ \\ ${ }^{1}$ Post Graduate Program, Sebelas Maret University Surakarta, Indonesia \\ Correspondence: Yustiana Olfah, Ir. Sutami Street Number 36 A, Jebres, Pucangsawit, Surakarta, Central Java, \\ Indonesia. Tel: 62-813-4531-9767.E-mail : yustinjogja67@student.uns.ac.id
}

Received: March 7, 2020 Accepted: May 20, 2020 Online Published: June 8, 2020

doi:10.5539/gjhs.v12n8p96 URL: https://doi.org/10.5539/gjhs.v12n8p96

\begin{abstract}
Objective: Violence in children is a phenomenon like an iceberg, more victims do not report than report to related parties. This study will observe the trends of sexual violence that occurred in Sleman Regency, Yogyakarta City in 2015-2018, and see community participation in preventing sexual violence against children to provide advice for policymakers in making regulations regarding sexual violence against children to create a bright generation.

Method: This research was a descriptive cohort study with a survey method. The sample of the research was 321 children aged 2-18 years in Sleman Regency. This research was done from 2015 to 2018. The data was collected then processed by using linear regression analysis.

Result: The regression coefficient of the relationship variable with the victim has a positive but very weak effect on sexual violence in children, 2, 419 with a confidence level of $95 \%$ at the limit of $0.006-0.061$, which means that the relationship with the victim increases the number of child abuse by $2.419 \%$. The coefficient of the location of the incident has a positive effect on sexual violence on children, 2, 800 with a confidence level of $95 \%$ at the limit of 0.12 to 0.70 , which means the location of the effect on the incidence of sexual violence on children.

Conclusion: Victims of violence that occur in girls in the elementary-junior high school age range, the Government of Sleman Yogyakarta through the Technical Implementation Unit for the Protection of Women and Children (UPTD PPA) provides counseling to restore children's mentality so that they can return to society in good condition and avoid violence sexual future. For children to avoid sexual violence against children, sexual education needs to be given starting from the basic layer, namely the family level, besides that parents must be able to play a maximum role in giving attention and protection to realize safety for children.
\end{abstract}

Keywords: child sexual violence, participation, prevention of child sexual violence

\section{Introduction}

Various negative phenomena occur in children, including sexual violence on children which is very common, both at school, at home, and in public places. The National Women's Commission mentions 15 forms of sexual violence namely rape, sexual harassment, sexual exploitation, sexual torture, sexual slavery, intimidation / sexual assault including threats or attempted rape, forced prostitution, forced coercion, forced coercion, abortion, coercion of marriage, trafficking of women for purposes of rape sexual, sexual control including coercion to wear clothing and criminalization of women through discriminatory rules based on morality and religion, punishment inhumane and sexual nuances, traditional sexual practices that endanger or discriminate against women who were last forced to use contraception/sterilization (Ministry of Women and Child Empowerment, 2016; Ministry of Health, 2015; Tedja, 2016).

Sexual violence in children cannot be considered mild because emotionally it causes stress, depression, mental shock, guilt appears so that blame yourself, arises fear of contact with others, always imagined with events that have ever happened to him, having nightmares, insomnia/insomnia, fear of certain objects or fear of certain places and issues of self-esteem (Weber, 2010). Physical impacts due to sexual violence on children include sexual dysfunction, somatic complaints, unwanted pregnancy, chronic pain, contracting skin diseases, contracting sexually transmitted diseases to addiction to viewing pornographic films (Irish \& Kobayashi, 2010; Fentahun, Assefa, \& Alemseged, 2012; Naluria \& Penny, 2018).

Children who are victims must be helped by us to fight for their rights and protect their confidentiality and need to 
be given psychological therapy so that children continue to be enthusiastic in managing their future days (Fauziah, Arini, \& Santoso, 2015). The government has made regulations to protect children from violence so that they can guarantee and protect children and their rights so that they can live, grow, develop and participate optimally according to human dignity and dignity and get protection from violence and discrimination (Mardina, 2018a; Fariani \& Paramastri, 2015).

In dealing with sexual violence against children, parents must know to be more open and informative to children, especially regarding sexual education to provide maximum assistance to avoid children from sexual abuse (Kirby, 2002). Parents play the role of providing initial information about sexual education in children to be one of the factors that will affect the development of life in children in the future (Naluria \& Penny, 2018).

The responsibility of children is not only held by their respective parents. In the Child Protection Act, all levels of society are required to take an active role in protecting Indonesian children including the school and the wider community. Especially for environments that have a history of child sexual abuse. The community has a very strong contribution in efforts to prevent sexual violence against children. An environment which is considered safe for children may not be safe, because crime can be done because of the opportunity, for that, the community together must narrow the space for potential sexual offenders, by both caring and willing to open their voices when they see distorted things happen (Shrivastava, Karia, \& Sonavane, 2017).

Government programs related to efforts to prevent and eradicate violence or sexual crimes against children, both directly and indirectly have been implemented. The concept of nurturing involves the role of parents in assisting and guiding all stages of a child's growth, caring for, protecting, and directing the new life of the child in each of its developments. Care is closely related to the ability of family and community in terms of providing attention, time, support to meet the physical, mental, and emotional and social needs of children who are in their infancy (Ministry of Health, 2015; Mardina, 2018a).

Based on data from the Office of Community Empowerment and Women (KPMP) of Yogyakarta City, in 2011 there were 142 cases of violence against children, this case increased in 2012 by 265 cases. In 2013 there were 691 cases, in 2014 there were 642 cases and in 2015 there were 626 cases. In the 2010 BPPM report cases of sexual violence against children that could be handled by the authorities in the city of Yogyakarta were 178 cases (Women's and Community Empowerment Agency, 2015a; Ministry of Women and Child Empowerment, 2016). The child protection commission shows that violence against children increased in 2015 with 2,989 reports of violence against children, $62 \%$ were sexual crimes. This data increased from 2,737 reports in the previous year and did not rule out the possibility of many unreported incidents. According to the Women's and Community Empowerment Agency in 2016, 356 cases of sexual violence occurred in Sleman Regency in 2014 while in 2015 it increased to 620 cases. Perpetrators of sexual violence against children consist of adults and children. Also, most perpetrators are close to the victim or in the same neighborhood as the victim (Kirby, 2002; Fentahun, Assefa, \& Alemseged, 2012; Mardina, 2018b).

The strategy of implementing child protection activities among regional apparatus organizations (OPD) in Sleman Regency has different roles and functions, but in the implementation, there is always coordination by the responsibilities of each village apparatus so that the number of sexual violence against children in Sleman Regency decreases. There has been no research on trends and issues of sexual violence against children in Indonesia, this study will provide an overview of sexual violence against children during the last three years, especially in the Sleman Regency of Yogyakarta Special Region so that people are more aware of the impact of sexual violence on children.

\section{Research Methods}

This research method is descriptive with the main objective to provide an objective, natural, and human engineering description of trends in sexual violence against children in the Sleman Regency. Taking data from analysis units or samples from existing populations then these samples are generalized as populations and use a questionnaire to collect the main data. This research was carried out based on existing documents in the Technical Implementation Unit of the Women's Protection Area for Children (UPTD PPA) Sleman Regency from 2015-2018 with a population of children aged 2-18 years in Sleman Regency Yogyakarta Special Region. The sample of the study was 321 children aged 2-18 years in Sleman Regency.

The data used are secondary data obtained by the UPTD PPA which is a unit of the Women's Empowerment and Child Protection Office for Population and Family Planning Control (P3AP2KB Office) from 2015-2018. The data collected was then analyzed using frequency distribution techniques in the basic data including gender, education, relationship with victims, and age. A Chi-square correlation test is used to determine the relationship of each dependent and independent variable. Finally, the linear regression test is to find out how much influence the 
independent variable has on the dependent variable. This study also uses a qualitative approach with a descriptive type to explore issues related to sexual violence in children and the form of community participation in the prevention of violence against children to describe the current situation of sexual violence against children and community participation.

\section{Results}

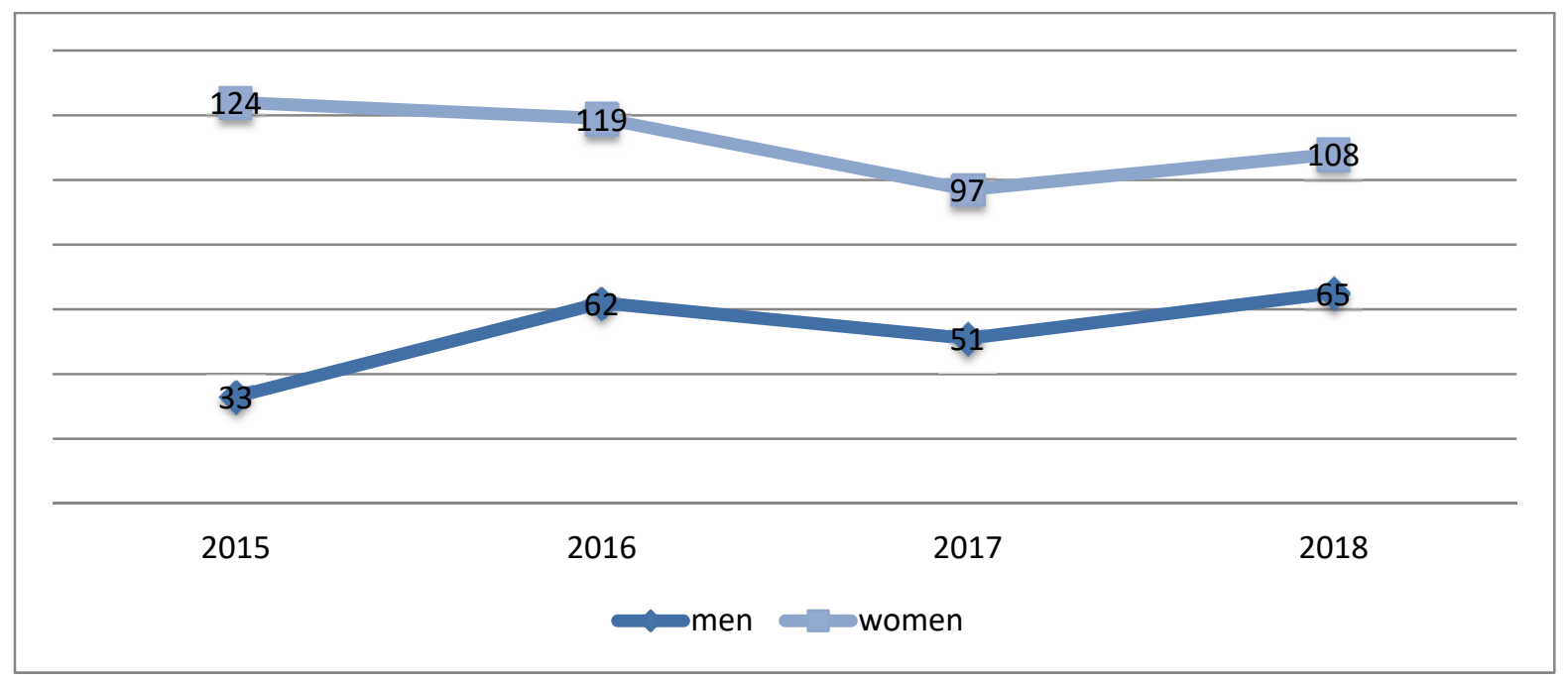

Figure. Trend of Violence Victims in Children by Gender Period 2015-2018

Women tend to be weaker than men, especially in cases of violence, in 2015 there were 124 victims of violence against girls, this case declined slightly until 2018 to 108 victims. Victims of sexual violence not only occurred in girls, but boys who were registered as victims of violence in 2015 were also 33 victims, this case has increased to 65 cases in 2018 .

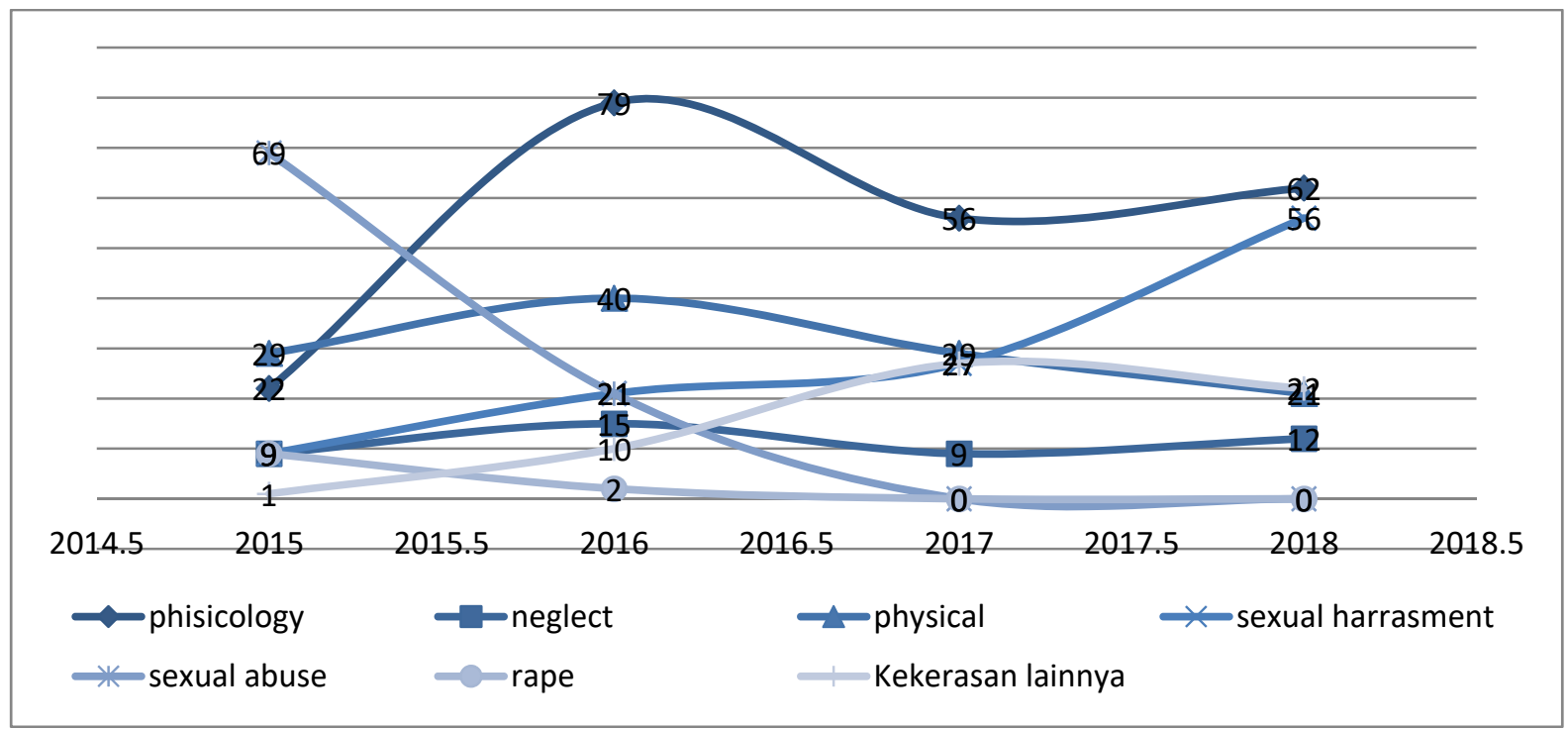

Figure 2. Trend of Form/Type of Violence in Children Period 2015-2018

Forms of violence against children include physical, psychological abuse, sexual abuse, neglect, rape, sexual harassment and other forms of violence. From the picture above psychological violence occupies the highest number of 62 victims, followed by sexual harassment which has increased the number of victims from 2015 to 2018 which is as many as 56 victims. Other forms of physical violence decreased from 2016-2018 with the same number of victims of physical violence as many as 21 in 2018. The number of victims of child neglect from 2015 to 
2018 tends to be stable with a total of 12 victims in 2018. Rape victims during the last two years no data has been reported.

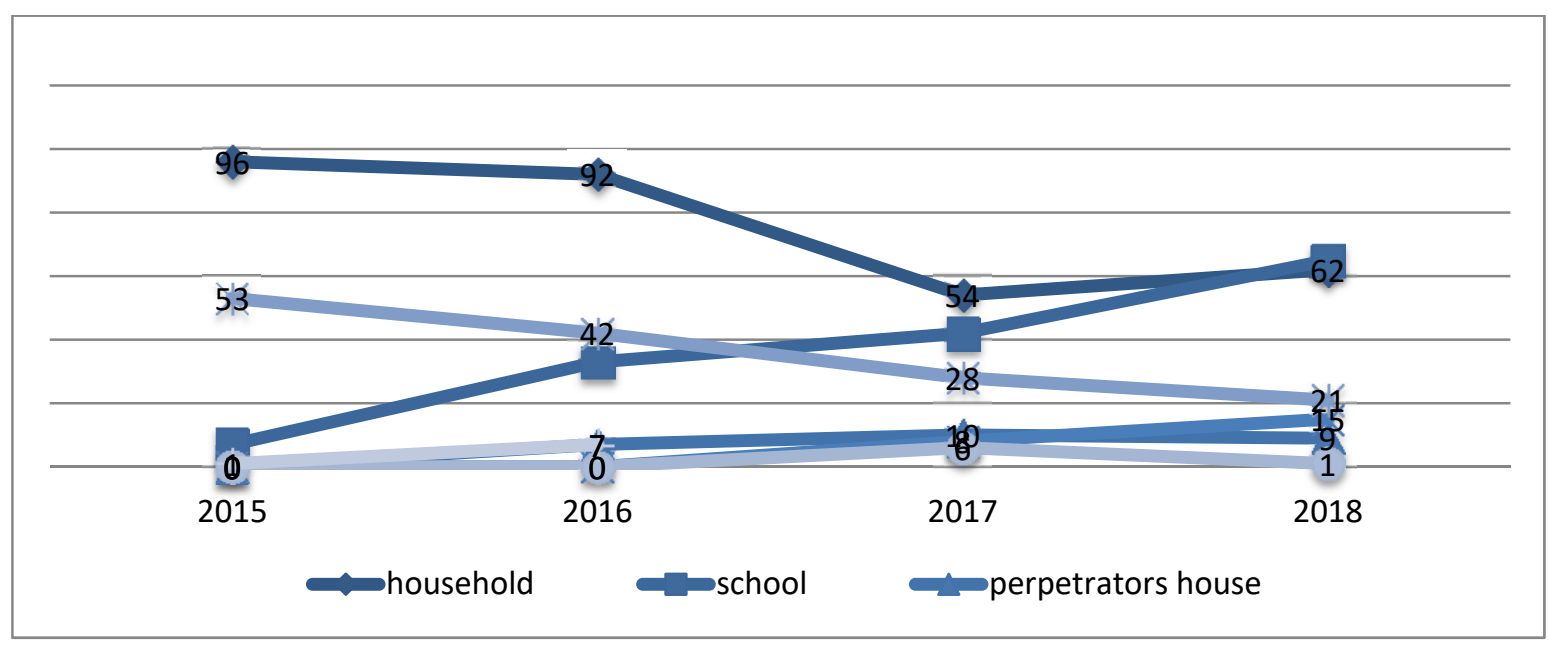

Figure 3. Trend Location of Violence Occurrence in Children Period 2015-2018

The highest number of locations of occurrence of violence in children in schools is 62 cases, this number continues to increase from year to year. Lack of supervision of children at school creates opportunities for perpetrators of violence against children. Besides that, the number of teachers and employees that are not proportional to the number of students causes the low quality of supervision in schools. The location of the second most violent incidents is in the household but this number continues to decline from 2015 to 2018 . The awareness of victims to report these incidents has deterred the perpetrators from being violent.

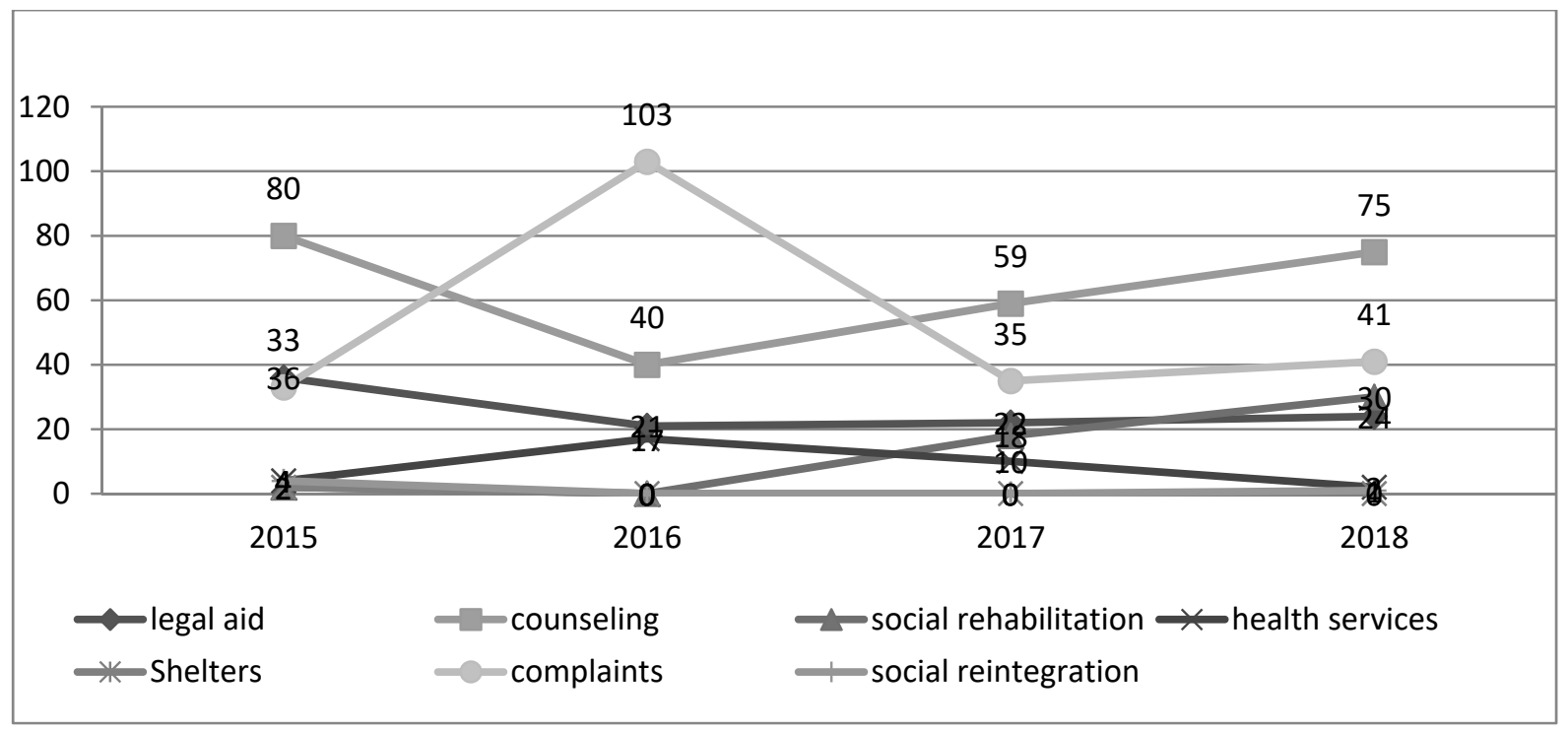

Figure 4. Trend of Violence on Children's Services for the Period of 2015-2018

Services provided by the government in handling cases of violence against children are mostly counseling and complaints. In 2015 the highest number of counseling services compared to other services, but in 2016 this number decreased to 40 cases than in 2018 it increased again to 75 cases while the number of complaint services in 2015 was 36 cases. This service tripled in 2016 to 103 cases, the number of cases that have been handled by the government makes this number continue to decline until 2018 to 41 cases. 


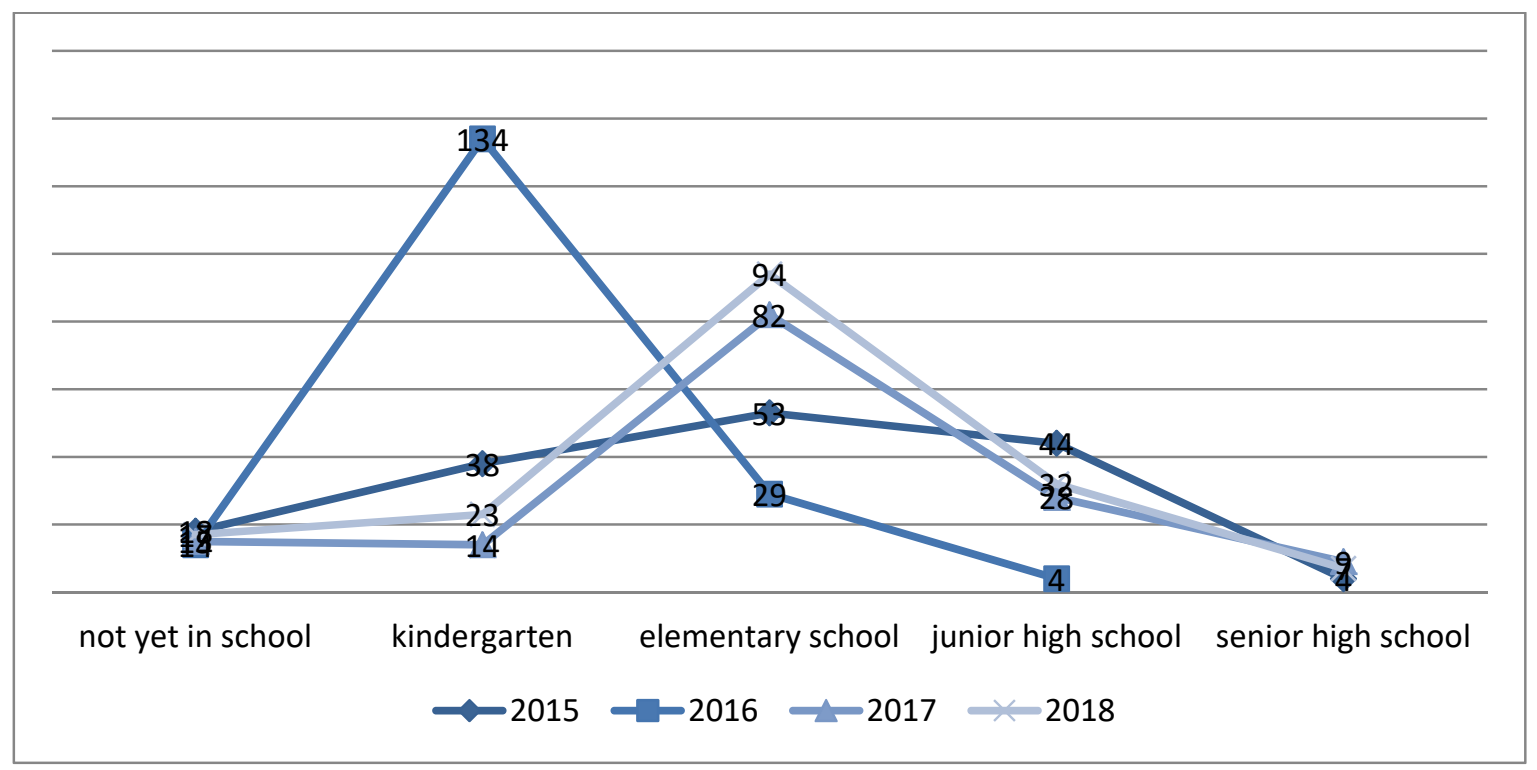

Figure 5. Trend of Child Violence Based on Education Level of Victims for the Period of 2015-2018

Victims of violence against children are most striking in 2016 with a range of kindergarten age as many as 134 cases. In 2018 the number of victims of kindergarten violence has decreased to 23 cases. The highest number of victims of violence in elementary school children in 2018 was 94 cases, this year is the highest number from the previous years besides the highest number of victims of violence in elementary school children compared to other age groups. The highest number of victims of violence in junior high school children in 2015 was 44 cases, this number continues to decline until 2018 to 22 cases.

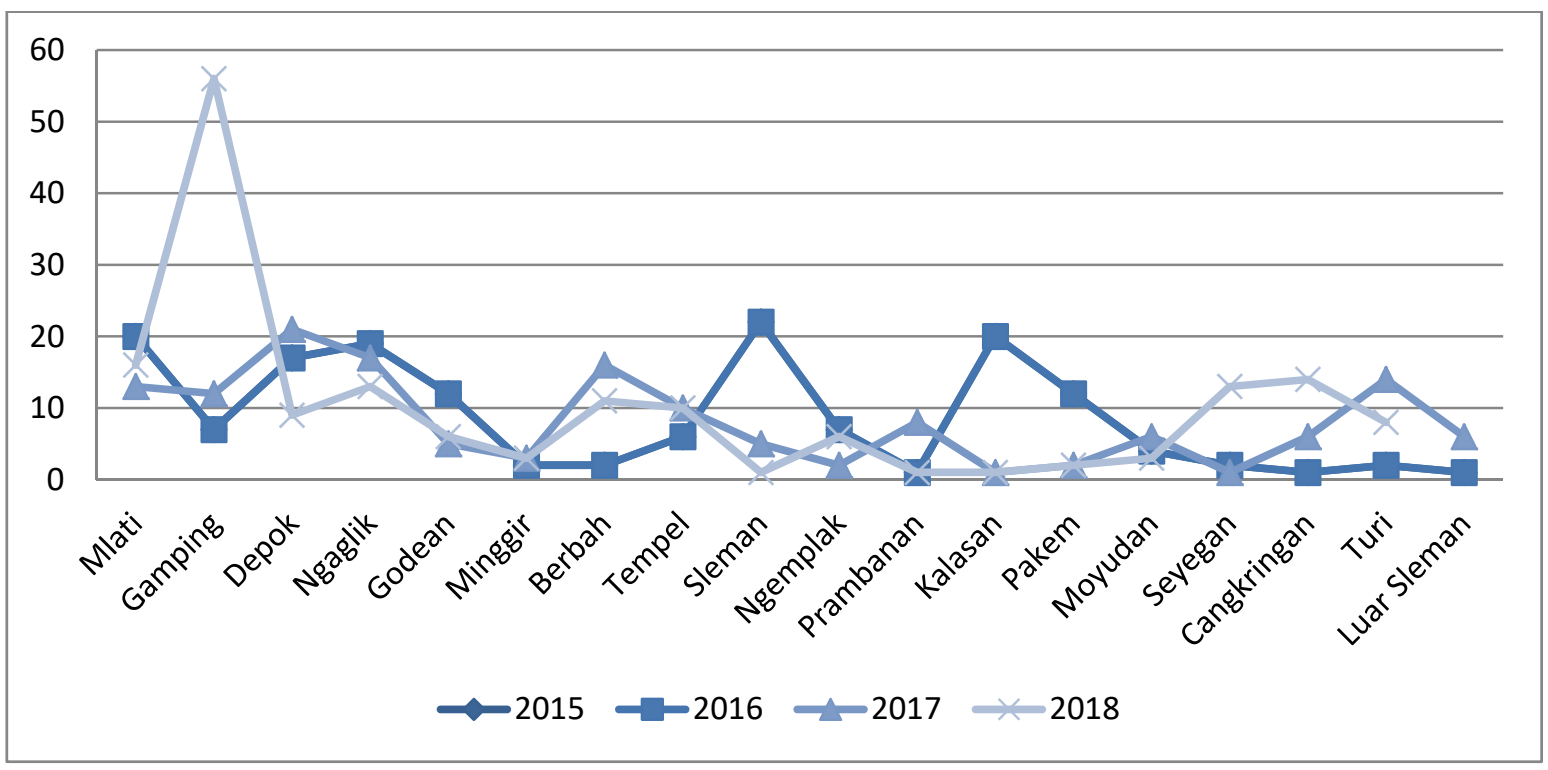

Figure 6. Trend of Districts Prone to Child Sexual Violence in the Period of 2015-2018

Based on districts prone to sexual violence against children, Gamping District occupies the highest number in 2018 as many as 57 cases. This figure is the highest compared to the previous year and compared to other districts. In 2017 the highest number of sexual violence against children in Kecamatan was Depok District with 20 cases. In 2016 Depok Subdistrict occupied the highest number of 23 cases then followed by Kalasan District of 20 cases. 
Table 1. Relationship between characteristics of victims and types of child abuse: sexual harassment in Sleman Regency Yogyakarta Special Region

\begin{tabular}{|c|c|c|c|c|}
\hline \multirow{2}{*}{ Variable } & \multicolumn{2}{|c|}{ Sexual harassment $(\mathrm{n}=321)$} & \multirow{2}{*}{ rho } & \multirow{2}{*}{ Sig. (2-tailed) } \\
\hline & Yes & no & & \\
\hline \multicolumn{5}{|l|}{ Sex } \\
\hline men & 15 & 101 & \multirow[t]{2}{*}{,- 227} & \multirow[t]{2}{*}{, $000 * *$} \\
\hline women & 69 & 136 & & \\
\hline \multicolumn{5}{|l|}{ Education } \\
\hline Not in school & 4 & 28 & \multirow{5}{*}{,- 040} & \multirow{5}{*}{,475 } \\
\hline Kindergarten & 13 & 24 & & \\
\hline Elementary School & 47 & 129 & & \\
\hline Junior High School & 16 & 44 & & \\
\hline Senior High School & 4 & 12 & & \\
\hline \multicolumn{5}{|l|}{ Relationship with victims } \\
\hline Husband and wife & 11 & 54 & \multirow{6}{*}{$-0,255$} & \multirow{6}{*}{, $000 * *$} \\
\hline Boyfriend/close friend & 21 & 65 & & \\
\hline Parents & 6 & 72 & & \\
\hline Childs & 1 & 5 & & \\
\hline neighbors & 8 & 3 & & \\
\hline others & 37 & 38 & & \\
\hline \multicolumn{5}{|l|}{ Village status } \\
\hline Rural & 6 & 25 & \multirow{3}{*}{,- 026} & \multirow{3}{*}{,648 } \\
\hline Urban & 74 & 198 & & \\
\hline Outside of Sleman District & 4 & 14 & & \\
\hline \multicolumn{5}{|c|}{ Locations of Case Occurrence } \\
\hline Household & 12 & 104 & \multirow{6}{*}{,- 232} & \multirow{6}{*}{, $000^{*}$} \\
\hline Victims house & 5 & 18 & & \\
\hline Perpetrators house & 15 & 4 & & \\
\hline School & 29 & 78 & & \\
\hline Rental/boarding & 6 & 1 & & \\
\hline Public place & 17 & 32 & & \\
\hline Age $($ mean $\pm S D)$ & \multicolumn{2}{|c|}{$11,23 \pm 4,194$} &,- 012 & ,835 \\
\hline
\end{tabular}

Sex with sexual violence in children has a significant relationship $(p=0.00)$. Girls who were victims of violence in this study most often occurred in kindergarten and elementary school age. Girls become a group that is very vulnerable to sexual violence because children are always positioned as physically, mentally and socially weak so that they have a high dependency on the adults around them. This condition causes the victim to be dominated and have difficulty to reveal it. Often sexual violence is carried out under violence and followed by threats so that victims are not. However, not a few perpetrators of sexual violence against children do this action without violence but use psychological manipulation by controlling children so that children are easily cheated, threatened with violence or non-violence to follow the wishes of the perpetrators. Children as individuals who have not reached the level of maturity, have not been able to judge something like a trick or not (Ministry of Women and Child Empowerment, 2016; Choudhry, 2018). The relationship between the victim and the incidence of sexual violence against children has a significant relationship (0.00). The close relationship referred to in this study is the victim's girlfriend. Close relationships with peers encourage conformity, causing negative behavior that leads to sexual 
activity. The distance between a child's home and the adjacent offender and often playing together becomes an easy cause for perpetrators of violence to invite and force the victim to follow his orders. Behavior like this can be repeated and encroach on the treatment of sexual violence.

The location of the incident was related to child sexual abuse with a significance value of $0.00<0.05$. Location is a causal factor that becomes a supporting factor for sexual violence because a safe place makes it easy for the offender to do everything he wants. Lack of supervision of children at school creates opportunities for perpetrators of violence against children. Besides that, the number of teachers and employees that are not proportional to the number of students causes the low quality of supervision in schools. According to Mannon, et al., School locations that are often used by perpetrators of sexual violence in children are toilets and school health unit.

Table 2. Results of linear regression analysis of predictors of child abuse: sexual harassment in Sleman Regency in 2015-2018

\begin{tabular}{|c|c|c|c|c|c|c|}
\hline \multirow{2}{*}{ Variable } & \multirow{2}{*}{$\mathrm{t}$} & \multicolumn{2}{|c|}{$\begin{array}{l}\text { Model } 1 \\
\text { (CI 95\%) }\end{array}$} & \multicolumn{3}{|c|}{$\begin{array}{l}\text { Model } 2 \\
(\text { CI 95\%) }\end{array}$} \\
\hline & & $\begin{array}{l}\text { Lower } \\
\text { Bound }\end{array}$ & $\begin{array}{l}\text { Upper } \\
\text { Bound }\end{array}$ & & $\begin{array}{l}\text { Lower } \\
\text { Bound }\end{array}$ & $\begin{array}{l}\text { Upper } \\
\text { Bound }\end{array}$ \\
\hline Sex & ,795 &,- 064 & ,152 & & & \\
\hline Age & 1,134 &,- 007 &, 027 & & & \\
\hline Education & $-1,794$ &,- 147 &, 007 & & & \\
\hline Relationship with victim & $2,419^{*}$ &, 006 &, 061 & $5,114^{* *}$ &,- 083 &,- 037 \\
\hline City status &,- 015 &,- 136 &, 134 & & & \\
\hline servica &,- 365 &,- 047 &, 032 & & & \\
\hline Scene & $2,800^{* *}$ &, 012 &, 070 & $4,702 * *$ &,- 085 &,- 035 \\
\hline Difable & ,449 &,- 277 & ,441 & & & \\
\hline $\mathrm{N}$ & 321 & & & 321 & & \\
\hline $\mathrm{R}^{2}$ & $5,6 \%$ & & & $12,6 \%$ & & \\
\hline F & 2,294 & & & 22,879 & & \\
\hline
\end{tabular}

$* \operatorname{sig} \alpha<0,05 ; * * \operatorname{sig} \alpha<0,001$.

The regression coefficient of the relationship variable with the victim has a positive but very weak effect on sexual violence in children, 2, 419 with a confidence level of $95 \%$ at the limit of $0.006-0.061$, which means that the relationship with the victim increases the rate of violence on children by $2,419 \%$. The coefficient of the location of the incident has a positive effect on sexual violence on children, 2, 800 with a confidence level of $95 \%$ at the limit of 0.12 to 0.70 , which means the location of the effect on the incidence of sexual violence on children.

The absence of social control is the originator of the occurrence of sexual violence on children. In the pattern of sexual abuse outside the family, the offender is usually an adult who is known by the child and has built relationships with the child and then entices the child into situations where the sexual abuse is committed, often by giving certain rewards that the child does not get in his home. Children usually remain silent because if they are known they are afraid that it will trigger anger from their parents. Also, some parents sometimes care less about where and with whom their children spend their time. Another factor that affects sexual violence on children is the availability of locations that are considered safe by perpetrators to carry out sexual violence against children. In Indonesia, places that are usually used as locations for sexual violence are schools: toilets, school health units, libraries, laboratories, and classrooms.

\section{Discussion}

\subsection{Trends of Sexual Violence in Children}

Sexual violence is carried out under violence and is followed by threats so that victims are helpless. This condition causes the victim to be dominated and have difficulty to reveal it. However, not a few perpetrators of sexual violence against children do this action without violence, but by using psychological manipulation. Children are 
deceived, so they follow their desires. Children as individuals who have not reached the level of maturity have not been able to judge something like a trick or not. Sexual violence against children can be seen from a biological and social perspective, all of which are related to the psychological impact on children (Fentahun, Assefa, \& Alemseged, 2012; Choudhry, 2018).

Biologically, the vital organs of a child before entering puberty are not prepared for sexual intercourse but if forced can damage the sexual tissue of an immature child. Meanwhile, from a social point of view, sexual drive is acted in secret, of course, the perpetrator does not want to be known by others. Perpetrators will try to make victims not to tell this to anyone (Irish \& Kobayashi, 2010; Simons, 2013). One of the most possible ways to do this is to intimidate. When a child is threatened than at that time naturally the child's body also defends or rejects it. When the biological body of a child refuses, then coercion carried out by a pedophile will increasingly cause injury and pain. When that means violence occurs. This pain and threat is certainly a traumatic experience for children (Tanaka, Suzuki, Aoyama, \& Takaoka, 2017).

The child will always experience the feeling of being gripped until the child dares to seek protection while to say, the child is always haunted by intimidation and threats from the offender. Pain and intimidation can also be an effect of psychological violence on children. In carrying out sexual violence against children, there are usually stages carried out by perpetrators. In this case, it is possible that the offender tried the behavior to measure the victim's comfort. If the victim complies, the violence will continue and be intensive, in the form of 1) Nudity; 2) Disrobing; 3) Genital exposure; 4) Observation of the child (when bathing, naked, and when defecating); 5) Kissing children who wear underwear; 6) Fondling (groping the victim's chest, genitals, thighs, and buttocks); 7) Masturbation; 8) Fellatio (stimulation of the penis, victim or the perpetrator himself); 9) Cunnilingus (stimulation of the vulva or vaginal area, on the victim or perpetrator); 10) Digital penetration (in the anus or rectum); 11) Penile penetration (in the vagina); 12) Digital penetration (in the vagina); 13). Penile penetration (in the anus or rectum); 14) Dry intercourse (stroking the offender's penis or other genital areas, thigh, or buttocks of the victim) (Fariani \& Paramastri, 2015; Mardina, 2018a).

Seeing the impact caused by sexual violence experienced by children who are victims, then in handling sexual violence against children is very important the active role of society, individuals, and government. A system-based approach is needed in dealing with child sexual violence. An effective child protection system requires interrelated components. These components include a social welfare system for children and families, a justice system that complies with international standards, and mechanisms to encourage appropriate behavior in society. Besides, a legal and policy framework is needed that supports and data and information systems for child protection (Fauziah, Arini, \& Santoso, 2015).

\subsection{Issues of Sexual Violence in Children}

The issue of child sexual abuse based on the results of interviews with stakeholders who are members of the forum for handling victims of violence (FPKK) in Sleman Regency related to violence against children including sexual violence that continues to occur, among others, caused: "The internet and social media are very influential on children's development, how to control and monitor smartphone usage. in children."

One of the things considered to trigger sexual violence against children is technological advances. The rise of sexual violence against children when viewed from the side of the perpetrators is related to the ease of obtaining information, especially concerning pornography and porno-action. This condition is extraordinarily massive with the presence of increasingly sophisticated and proliferating mobile phones among the people so that it affects access to pornography that is easily accessible and cannot be controlled. Related to this problem, the child protection agency (LPA) invites the community to combat sexual violence against children and also calls for violence and sexual harassment to occur anytime, anywhere and to anyone. Both biological children, and children around us. The threat to child sexual violence is everywhere, at any level, any social stratum is always there (Naluria \& Penny, 2018).

According to stakeholders who are members of the forum for handling victims of violence (FPKK) in Sleman Regency (Police PPA Unit): so that in some cases there was sexual violence against children in these locations. Besides that, Sleman Regency also has many tourist attractions so there are so many hotels with various categories in some cases of sexual violence against children in that location. "Special Region of Yogyakarta (DIY) is still the destination of the visit tourists, both from foreign countries and the archipelago. The tourism potential in DIY is quite diverse, there are many interesting tourism objects to visit, including Sleman Regency”. As its development, Sleman becomes a city of education and tourism (Tedja, 2016). Tourism development in addition to having a positive impact on development programs. Along with the rapid development of entertainment venues, lodging, and other facilities which basically aims to attract tourists, but on the other hand, cause social change in society. 
Changes that occur such as lifestyle, how to dress, free life behavior to the individualist attitude and materialism shown by the community (Fariani \& Paramastri, 2015) .

\subsection{Community Participation in Preventing Sexual Violence Against Children}

The community has an effort to protect children from sexual crimes by forming a rapid reaction team to protect children. The team is tasked with conducting prevention and early detection of sexual crimes in the neighborhood. The team can be formed at the village or neighborhood level (RT) by involving youth clubs, RT heads, village heads, PKK, and local environmental security officers. They play a role in conducting socialization, education, and information on reproductive health. The impact of sexual crimes on child development and child empowerment is given periodically. The aim is to change the views of some people who still consider sexuality as a taboo (Trimaya, 2016).

The presence of cadres, especially cadres from women including institutions or mass organizations at the village or kelurahan level is expected to play an active role in taking part in preventing acts of violence against children. Since children mostly grow and develop within the family and the surrounding environment, the role of village activists is very important especially to build a collective awareness of the community about the needs and rights of children who must be protected from various forms of violence, intimidation, and exploitation. Not only parents or immediate family can do violence but anyone can be a perpetrator so prevention of violence can be done by fostering the closeness of children with parents from birth.

The stakeholders of the Sleman Regency (UPTD PPA) forum for handling victims of violence (FPKK) said: "PKDRT cadres can be escorted if necessary to report, provide education to the community to prevent cases of violence against women and children. Acts of domestic violence are closely related to behaviors and events that are very likely to be found in daily life, PKDRT cadres in Sleman Regency which are spread over 86 villages from 17 sub-districts are the spearhead in preventing domestic violence. Besides, they have the task of detecting and handling victims of domestic violence including sexual violence against children. "Government socialization has been running since the regulation on child protection was imposed but the awareness of the village community to participate is still small so it needs to be balanced with the synergy between layers of society to make it more optimal. The effort can be in the form of providing character education in all elements of government and school children by limiting night spots for children, limiting the use of motorbikes and cellphones." The government needs to change the pattern of socialization in the field so that the core of education to foster community participation in preventing violence against children can be conveyed (Naluria \& Penny, 2018; Fauziah, Arini, \& Santoso, 2015; Women's and Community Empowerment Agency, 2015b).

The stakeholders of the Sleman Regency District Violence Management (FPKK) forum (PPA P3P2KB Department) said: "The Sleman Regency Government, Special Region of Yogyakarta, initiated child-friendly villages accompanied by the Community-Based Integrated Child Protection Movement (PATBM). The initial step that has been taken is to establish a Guideline for the Development of the Integrated Child Protection Movement for the Community "PATBM Sumringah" Through the Decree of the Head of DP3AP2KB number $101 /$ Kep.Kadin / 2017." The PPA Task Force is a tangible form of community participation in preventing violence against children.

Promotive and preventive efforts on child sex crime, the National Movement Against Sexual Crimes Against Children (GN AKSA) is carried out starting from the family, school, and community. In the family environment, parents play an important role in determining the attitude and character of children. Parents must provide children with the right information and knowledge about sex provided early on in the right way and time following the level of development and maturity of the child so that children will be able to prepare themselves in facing various threats that will harm their future. Two-way communication between parents and children is also needed because children are now more vulnerable to problems. Also, children's efforts need to be made because the influence of television and cyberspace is very large (Shields, 2016)

The stakeholders in the handling forum for victims of violence (FPKK) of Sleman Regency (Education Sector of the Sleman Regency Education Office) said: "Education is one of the priority sectors supporting the realization of child-friendly districts. Until 2018 there have been 70 schools with a child-friendly concept developed by the Sleman Regency Government consisting of elementary, junior high schools or equivalent. We have set priorities for sectors that are felt to have a large impact on child development, one of which is education. "The health sector stakeholder in the Sleman District Health Handling Forum (FPKK) (the public health sector of the Sleman Regency Health Office) said: Community Health Centre (Puskesmas) are at the same time predicated as child-friendly puskesmas." 
Concern and the active role of all levels of society are needed in protecting the rights of children. But to be able to play an active role in the protection program, the community needs to be given guidance and insight knowledge, especially about the needs, parenting, environment, and fulfillment of the basic rights of children. Given that most children grow and develop in the family and neighborhood.

\section{Conclusion}

Sexual violence often occurs in girls, the location of this incident is mostly in schools and households. Children need to be equipped with sexual education so that children can fortify themselves from sexual violence committed by adults including those closest to them, besides that the control of the community needs to be improved so that children can grow and develop properly under the stage of their age regardless of the threat and intimidation of sexual violence. The family environment is the basis of education as well as protection so that children feel safe and comfortable to express what they have experienced. Communities in Sleman Regency actively participate as PKDRT cadres and PPA Task Force while in schools children-friendly schools are developed. From the health sector, all Community Health Centre (Puskesmas) in Sleman Regency has adopted the principle of being Child-Friendly Puskesmas.

\section{Competing Interests Statement}

The authors declare that there are no competing or potential conflicts of interest.

\section{References}

Choudhry, V. (2018) Child sexual abuse in India: A systematic review. PLoS One, 23(10). https://doi.org/10.1371/journal.pone.0205086

Fariani, A., \& Paramastri, I. (2015). Cadre Posyandu as Primary Prevention Agents for Sexual Violence in Children. Gadjah Mada Journal of Professional Psychology, 1(2).

Fauziah, A., \& Santoso, H. (2015). (2015). Sexual Violence in Children in Indonesia. Proceedings of Research and Community Service, 2.

Fentahun, N., Assefa, T., Alemseged, F., et al (2012). Parents' perception, students' and teachers' attitude towards school sex education. Ethiop J Health Sci, 22, 99-106.

Irish, L., \& Kobayashi, I., D. D. (2010). Long-term Physical Health Consequences of Childhood Sexual Abuse: A Meta-Analytic Review. Journal of Pediatric Psychology, 35(5). https://doi.org/10.1093/jpepsy/jsp118

Kirby. (2002) The impact of schools and school programs upon adolescent sexual behavior. J Sex Res, (39), 27-33. https://doi.org/10.1080/00224490209552116

Shields, M., Tonmyr, L., \& Hovdestad, W. (2016). Is child sexual abuse declining in Canada? Results from nationally representative retrospective surveys. Health promotion and chronic disease prevention in Canada: research, policy and practice, 36(11), 252. https://doi.org/10.24095/hpcdp.36.11.03

Mardina, R. (2018a). Infodatin Center for Data and Information Ministry of Health of the Republic of Indonesia, Violence Against Children and Adolescents. Jakarta.

Mardina, R. (2018b) Infodatin Pusat Data Dan Informasi Kementerian Kesehatan RI, Kekeradan Terhadap Anak Dan Remaja. Jakarta.

Ministry of Health. (2015). Strategic Plan Ministry of Health 2015-2019. Jakarta.

Ministry of Women and Child Empowerment. (2016). Community-Based Integrated Child Protection Guidelines/PTBM. Jakarta.

Naluria, \& Penny, U. (2018). Prevention of Violence Against Children in the Perspective of the Right to Sense of Security in West Nusa Tenggara. Journal of Human Rights, 9(2). https://doi.org/10.30641/ham.2018.9.1-17

Shrivastava, A. K., Karia, S. B., Sonavane, S. S., D. S. A. (2017) Child sexual abuse and the development of psychiatric disorders: a neurobiological trajectory of pathogenesis. Industrial Psychiatry Journal, 26(1), 4-12. https://doi.org/10.4103/ipj.ipj_38_15

Simons. (2013). Identifying Mediators of the Influence of Family Factors on Risk Sexual Behavior. Retrieved from www.proquest.search/index.com

Tanaka, M., Suzuki, Y. E., Aoyama, I., \& Takaoka, K., M. H. (2017). Child sexual abuse in Japan: A systematic review and future directions. Child Abuse \& Negl, 31, 31-40. https://doi.org/10.1016/j.chiabu.2017.02.041

Tedja, M. (2016). Economic Conditions and Sexual Violence in Children Magazine Short Info Social Welfare. 
Weber. (2010). Outcomes of child sexual abuse as predictors of laters sexual victimization. Journal of International Violence, 26(9), 1899-1905. https://doi.org/10.1177/0886260510372935

Women's and Community Empowerment Agency. (2015a). Gender and Children's Profile of 2015 in Yogyakarta. Yogyakarta.

Women's and Community Empowerment Agency. (2015b). Training Guide for Victims of Violence Against Women and Children Service Officers. Yogyakarta.

\section{Copyrights}

Copyright for this article is retained by the author(s), with first publication rights granted to the journal.

This is an open-access article distributed under the terms and conditions of the Creative Commons Attribution license (http://creativecommons.org/licenses/by/4.0/). 